\title{
Comparative Analysis of Distribution of Intertidal Fish Assemblages in Different Estuarine Systems on Northern Coast of Brazil
}

\author{
Milton Gonçalves da Silva Júnior ${ }^{1}$, Antonio Carlos Leal de Castro $^{2}$ \& Ulrich Saint-Paul ${ }^{3}$ \\ ${ }^{1}$ Faculdade Araguaia, Goiânia, Goiás, Brazil \\ ${ }^{2}$ Department of Oceanography and Limnology, Federal University of Maranhão, São Luís, Maranhão, Brazil \\ ${ }^{3}$ Leibniz Center for Tropical Marine Research (ZMT), Bremen, Germany \\ Correspondence: Milton G. Silva Júnior, Faculdade Araguaia, Avenida T-10, nº 1047, CEP: 74223-060, Goiânia, \\ Goiás, Brazil. Tel: 55-62-3274-3161. E-mail: professormiltonjunior@outlook.com
}

Received: September 29, 2016

doi:10.5539/jsd.v10n2p26
Accepted: December 25, 2016 Online Published: March 30, 2017

URL: https://doi.org/10.5539/jsd.v10n2p26

\begin{abstract}
The northern coast of Brazil has more than 30 estuaries distributed along $650 \mathrm{~km}$ of coastline. These conditions favor the presence of relatively large fish communities in estuarine environments, but published information on the fish fauna in tidal creeks in northern Brazil is only available for some mangrove systems, and comparative studies between fish estuarine communities in different tidal creeks are less common. The choice of the study area was based on the fact that it has been poorly investigated with regard to estuarine fish fauna in comparison in mangrove tidal creeks using the same fishing gear. The objective of the present study was to compare the composition of the relative biomass of taxonomic, functional and ecological guilds of fish assemblages occurring in estuarine systems along the northern coast of Brazil. The study area of the present comparative analysis extended from the southeastern edge of the Marajoara Gulf to the western edge of the Maranhense Gulf. A comparative analysis among different estuarine systems was performed using data from other studies. The abundance of juveniles was greater in the Caeté, Curuçá and Cururuca estuaries than other estuaries. Cluster analysis separated the estuaries into two distinct groups and significant differences between these groups only exist in relation to geographical proximity. The present investigation indicates that the coastal region between the states of Pará and Maranhão is characterized by high dynamics and environmental heterogeneity, particularly with regard to changes in river discharge and tidal fluctuations. The present results underscore the importance of ecological information on ichthyofauna in tropical estuaries in order to include appropriate descriptors in conservation or restoration processes of marine communities and habitats.
\end{abstract}

Keywords: ichthyofauna, functional and ecological guilds, tidal creeks

\section{Introduction}

The northern coast of Brazil hosts the longest continuous stretch of coastline colonized by estuarine mangrove forests in the world, accounting for 56.6\% of all mangroves in South America (Souza Filho, 2005). In this region, more than 30 estuaries are distributed along $650 \mathrm{~km}$ of coastline (Barletta et al., 2010), nine of which have been designated marine extractive reserves (Giarrizzo and Krumme, 2009).

Mangroves and their tidal creeks, which cover the estuarine system on the coast of the states of Pará and Maranhão, function as exporters of biomass, a source of nutrients and sediment maintainers and are conditioned by both tidal patterns and freshwater flow from hydrographic basins (MMA, 2002). These conditions favor the presence of relatively large fish communities in estuarine environments (Rozas and Zimmerman, 2000; Vidy, 2000). However, published information on the fish fauna in tidal creeks in northern Brazil is only available for some mangrove systems (Barletta et al., 2010). In general, most studies investigate the ichthyofauna communities of specific tidal creeks or analyze temporal patterns (Rountree and Able, 1997; Barletta-Bergan et al., 2002a; Layman and Silliman, 2002; Barletta et al., 2003; Spach et al., 2004).

Comparative studies between fish estuarine communities in different tidal creeks are less common (Giarrizzo and Krumme, 2007, 2008; Viana et al., 2010). For instance, Barletta et al. (2003) identified seasonal changes in the composition of fish assemblages in a macro-tidal region of the estuary of the Caeté River. Krumme et al. (2004) investigated the intertidal movements of fish (sensu Gibson, 1982) in the sub-tidal estuarine 
compartments of the Caeté River and its intertidal tributaries. Giarrizzo and Krumme (2007) described the composition of and seasonal changes in fish assemblages in four intertidal mangrove creeks in a homogeneous salinity zone of the mangrove estuary of the Curuçá River.

The choice of the study area in the present investigation was based on the fact that it has been poorly investigated with regard to estuarine fish fauna in comparison in mangrove tidal creeks using the same fishing gear. To date, records have been published by Giarrizzo and Krumme (2008) and Viana et al. (2010), who carried out comparisons of the fish fauna in tidal creeks, estuaries and non-estuarine bays along the northern coast of Brazil.

The main objective of the present study was to compare the composition of the relative biomass of taxonomic, functional and ecological guilds of the fish assemblages occurring in estuarine systems along the northern coast of Brazil, testing the null hypothesis that there is no spatial or seasonal variation in the composition, structure and diversity of fish assemblages and functional groups between tidal creeks in the estuarine systems investigated.

\section{Method}

\subsection{Study Area}

The study area of the present comparative analysis extended from the southeastern edge of the Marajoara Gulf to the western edge of the Maranhense Gulf (Fig. 1). The continental shelf is 562 to $640 \mathrm{~km}$ wide, with islands, sand banks and intertidal creeks. The high-intertidal zone is covered by approximately $7000 \mathrm{~km} 2$ of mangrove forests (Kjerfve and Lacerda, 1993).

The local estuarine systems are differently influenced by the Amazon estuary, approximately $250 \mathrm{~km}$ west of the Marajoara Gulf. Therefore, the Gurupi River, which divides this tract of coastline into two approximately equal parts, was used as a geographic reference to separate the estuaries into two groups: those to the west of this river (Curuçá and Caeté estuaries in the state of Pará) and those to the east of it (Anil, Caranguejos Island, Cururuca, Paciência and Tibiri estuaries in the state of Maranhão) (Fig. 1).

The estuaries west of the Gurupi River are characterized by semi-diurnal, meso-tidal to macro-tidal regimens (range: 2 to $5 \mathrm{~m}$ ) and relatively little freshwater input. In fact, the estuarization of the continental shelf and the high degree of turbidity of the waters in this area are largely determined by the Amazon River (Krumme and Saint-Paul, 2010).

The estuaries west of the Gurupi River have dynamic aspects similar to the Amazon estuary due to the greater amount of discharge. These rivers have vast floodplains with a strong marine influence and a greater variation in tidal range than the other group (up to $7 \mathrm{~m}$ ) (Stride, 1992; MMA, 2002) as well as a wider range of salinity in the mangrove systems (Giarrizzo and Krumme, 2007). The vegetation is predominantly mangrove and forms a belt of up to $30 \mathrm{~km}$ wide, penetrating as many as $40 \mathrm{~km}$ inland as mangrove forests. The mangroves are almost exclusively composed of Rhizophora mangle L., Avicennia germinans (L) Stearn and Laguncularia racemosa (L) Gaertn. 


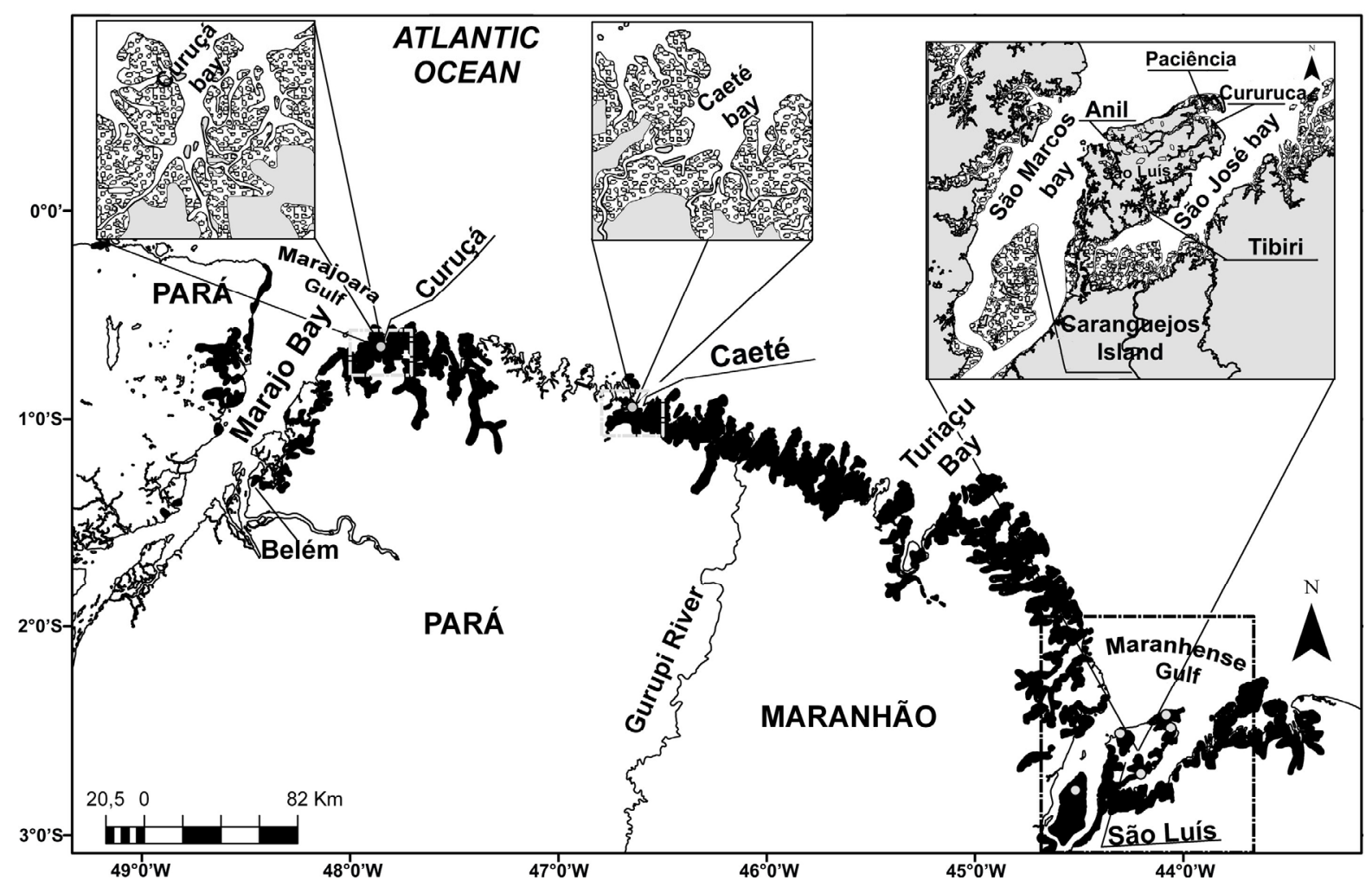

Figure 1. Northern coast of Brazil between states of Pará and Maranhão

\subsection{Sampling and Data Analysis}

The Paciência estuary (Maranhense Gulf) was sampled bimonthly with block nets between January 2006 and September 2007. Samples were collected in the same tidal creeks as those sampled by Castro (2001).

A comparative analysis among different estuarine systems was performed using data from SUDAM/UFMA (1983), Batista and Rego (1996), Castro (2001), Barletta et al. (2003), Pinheiro-Junior et al. (2005), Giarrizzo and Krumme (2007) and Carvalho-Neta and Castro (2008). In these studies, all sampling surveys were carried out using fixed fishing gear (block nets) set at the mouths of intertidal mangrove creeks.

Species nomenclature was standardized based on information from the FishBase (Froese and Pauly, 2010). The Shannon-Wiener diversity index was used to compare species compositions and explore the geographical variation in the ichthyofauna. Cluster analysis was conducted to explore the similarity among fish assemblages in different estuaries in terms of species composition. The matrix consisted of presence/absence data (Jaccard similarity index; PRIMER 6.0) software OPRIMER-E Ltd). A similarity profile (SIMPROF) was built to test the statistical significance of the clusters (Clarke and Warwick, 2001). All analyses were performed using the DivEs 2.0, PRIMER 6.0 and STATISTICA 7.0 programs.

\subsection{Ecological Classification}

Fish species were ecologically classified based on estuary use and functional feeding mode, following Elliott et al. (2007). Five guilds defined different primary estuary use: occasional marine visitors, marine estuarine-opportunists, marine estuarine-dependent species, estuarine residents and freshwater species. Six guilds defined different feeding strategies: herbivores, omnivores, detritivores, piscivores, zoobenthivores and zooplanktivores.

\section{Results}

The broadest salinity range was recorded in the Curuçá, Caeté, Cururuca and Paciência estuaries (Table I). A total of 139 fish species were recorded in the entire dataset and are given as supplementary material in Appendix. However, only eight species were found in all the estuaries surveyed: Batrachoides surinamensis (Bloch and Schneider, 1801) Cetengraulis edentulus (Cuvier, 1829), Chaetodipterus faber (Broussonet, 1782), Cynoscion acoupa (Lacepède, 1801), Cynoscion leiarchus (Cuvier, 1830), Genyatremus luteus (Bloch, 1790), Pseudauchenipterus nodosus (Bloch, 1794) and Sciades herzbergii (Bloch, 1794). Thirty-two species were 
located only in the estuaries west of the Gurupi River and 55 species were captured exclusively in the Maranhense Gulf (state of Maranhão).

The highest number of families and species was recorded by Castro (2001) in the Paciência estuary. The abundance of juveniles was $>80 \%$ in the Caeté, Curuçá and Cururuca estuaries and $<70 \%$ in the other estuaries.

Based on the findings of the survey, the Caeté and Curuçá estuarine systems (state of Pará) are apparently more diverse with regard to the number of families and species that the other estuaries (Maranhão). This interpretation is supported by a similar species-to-family ratio (Table I). The Shannon-Wiener diversity index also revealed similar values in the environments studied (Table I).

On a 25 -year time scale since the first records on fish fauna in the Paciência estuary, a sharp decline in species and family richness in the fish assemblages has been recorded (Table I). The opposite occurred with the Shannon-Wiener diversity index, which revealed an increase in variation over the same time period (Table I).

Most families identified exhibit a pattern of spatial occurrence. Comparing the percentage of biomass of the catches, several dominant families exhibit a spatial pattern. The highest percentage of Ariidae biomass was obtained in the tidal creeks of Caranguejos Island and the Anil estuary, where Sciades herzbergii (Bloch, 1794) contributed most to the catches. In the Tibiri estuary, the largest contribution was provided by Cathorops spixii (Agassiz, 1829) and, in the Caeté estuary, Cathorops agassizii made the largest contribution to the catch (Eigenmann and Eigenmann, 1888).

The families Engraulidae and Haemulidae were poorly represented in the biomass from the tidal creeks. Only the tidal creeks of the Cururuca estuary exhibited a high abundance of C. edentulus and Genyatremus luteus. In the Caeté estuary, Anchovia clupeoides (Swainson, 1839) accounted for the highest percentage of engraulid biomass in the first group of estuaries. Within Mugilidae, Mugil curema Valenciennes, 1836 and Mugil incilis Hancock, 1830 contributed most to the values recorded in the Paciência estuary and Mugil gaimardianus Desmarest, 1831 contributed most to those recorded in the Anil estuary.

In the Paciência and Tibiri estuaries, the family Sciaenidae was mainly represented by Cynoscion acoupa. A sharply larger relative biomass of species of Tetraodontidae was recorded in the Curuçá and Caeté estuaries, with larger catches in comparison to the other estuaries. Among the species that contributed most to the catches, only Ariopsis bonillai (Miles, 1945) and C. spixii have no commercial value.

The samples contained relatively few marine occasional visitors and freshwater fish. Marine occasional visitors were virtually absent from the estuarine system located in the inner region of the Maranhense Gulf. Freshwater fish were more abundant in the Cururuca and Anil estuaries.

Marine species contributed $>50 \%$ to the total biomass collected in the second group of estuaries, but $<6 \%$ in the first group. Moreover, estuarine residents contributed $>85 \%$ in the first group, and only $65.4 \%$ in the second one.

With regard to feeding mode functional groups, detritivores accounted for $>70 \%$ of the relative biomass in the systems of the first group, but only 26.0 to $55.1 \%$ in those of the second group (Table I). Detritivores and zoobenthivores accounted for $>50 \%$ of the fish biomass collected in the second group. Zooplanktivores and herbivores were more represented in the second group, where the estuarine systems are under a greater marine influence, as was the case of engraulids. Omnivores were the least abundant category in all the systems studied, except the Paciência and Anil estuaries, where they were only more abundant than zooplanktivores (Table I). 
Table 1. Comparative overview of relative biomass of taxonomic, functional and feeding categories of fish fauna in seven estuarine systems along coast of states of Pará and Maranhão, Brazil; (-) no data

\begin{tabular}{|c|c|c|c|c|c|c|c|c|}
\hline & \multicolumn{8}{|c|}{ Estuarine syste ms } \\
\hline & \multicolumn{2}{|c|}{ Pará } & \multicolumn{6}{|c|}{ Maranhão } \\
\hline & \multirow[b]{2}{*}{ Caeté $^{a}$} & \multirow[b]{2}{*}{ Curuçáb } & \multirow[b]{2}{*}{ Cururuca $^{c}$} & \multirow[b]{2}{*}{ Tibiri $^{\mathrm{d}}$} & \multirow[b]{2}{*}{ Paciência ${ }^{e}$} & \multirow[b]{2}{*}{ Anil $^{f}$} & \multirow{2}{*}{$\begin{array}{c}\text { Carangue jos } \\
\text { Island }^{\mathrm{g}}\end{array}$} & \multirow{2}{*}{$\begin{array}{c}\text { Paciência } \\
\text { (present study) }\end{array}$} \\
\hline & & & & & & & & \\
\hline Salinity range & $6.0-35.0$ & $6.1-40.8$ & $1.5-38.0$ & $2.3-28.1$ & $2.6-38.3$ & - & $5.0-25.0$ & $11.5-35.0$ \\
\hline Number of families & 26 & 31 & 21 & 22 & 33 & 23 & 19 & 27 \\
\hline Number of fish species & 49 & 65 & 49 & 34 & 75 & 43 & 32 & 55 \\
\hline Number of species exclusively caught in the study & 8 & 21 & 7 & 1 & 13 & 3 & 1 & 7 \\
\hline Species/family ratio & 1.9 & 2.1 & 2.3 & 1.5 & 2.3 & 1.9 & 1.7 & 2.0 \\
\hline Abundance of juveniles (\%) & 80.0 & 90.0 & 79.6 & 52.4 & - & - & 65.5 & 66.2 \\
\hline Shannon-Wiener diversity index & $0.6-1.1$ & - & 1.1 & $1.3-1.7$ & $1.2-1.4$ & 0.8 & $1.8-2.5$ & $0.3-1.2$ \\
\hline \multicolumn{9}{|l|}{ Dominant families ( $\%$ total catch mass) } \\
\hline Ariidae & 41.9 & 4.3 & 19.0 & 42.8 & 13.6 & 52.1 & 52.7 & 35.2 \\
\hline Engraulidae & 14.3 & 3.0 & 17.6 & 2.1 & 1.2 & 1.3 & 0.6 & 5.9 \\
\hline Haemulidae & 1.7 & 0.5 & 13.9 & 2.9 & 8.2 & 0.4 & 2.1 & 3.5 \\
\hline Mugilidae & 0.9 & 1.5 & 20.2 & 6.1 & 26.8 & 27.9 & 2.4 & 7.2 \\
\hline Sciaenidae & 3.3 & 0.8 & 9.9 & 29.7 & 18,0 & 3.0 & 6.8 & 22.4 \\
\hline Tetraodontidae & 27.1 & 88.4 & 0.4 & 2.3 & 4.1 & 3.7 & 7.9 & 7.1 \\
\hline \multicolumn{9}{|l|}{ Estuarine Use Functional Group (\% total catch mass) ${ }^{\mathrm{h}}$} \\
\hline Marine occasional visitors & 0.3 & $<0.1$ & 0.5 & - & 2.4 & - & - & - \\
\hline Marine estuarine-opportunist & 5.5 & 2.9 & 50.4 & 19.7 & 21.6 & 18.5 & 8.5 & 22.2 \\
\hline Marine estuarine dependent & 4.6 & 2.0 & 24.4 & 27.7 & 47.7 & 26.5 & 23.2 & 27.7 \\
\hline Estuarine residents & 87.7 & 94.9 & 20.5 & 51.5 & 27.7 & 46.7 & 65.4 & 49.3 \\
\hline Freshwater fishes & 1.8 & 0.2 & 4.1 & 1.1 & 0.6 & 8.3 & 3.0 & 0.8 \\
\hline \multicolumn{9}{|l|}{ Feeding Mode Functional Group (\% total catch mass) ${ }^{\mathrm{h}}$} \\
\hline Herbivore & 16.1 & 4.4 & 37.8 & 9.9 & 30.3 & 29.5 & 19.9 & 14.6 \\
\hline Omnivore & $<0.1$ & - & 1.6 & - & 2.7 & 0.2 & 0.2 & $<0.1$ \\
\hline Detritivore & 75.4 & 94.2 & 27.4 & 26.0 & 36.1 & 55.1 & 47.6 & 37.8 \\
\hline Piscivore & 1.6 & 0.3 & 8.1 & 29.1 & 12.5 & 3.8 & 20.1 & 16.3 \\
\hline Zoobenthivore & 5.8 & 0.8 & 20.2 & 34.9 & 18.0 & 11.3 & 11.4 & 31.1 \\
\hline Zooplanktivore & 1.1 & 0.3 & 5.0 & 0.2 & 0.4 & $<0.1$ & 0.9 & 0.2 \\
\hline
\end{tabular}

a (Barletta et al ., 2003);

b (Giarrizzo \& Krumme, 2007);

c (SUDAM \& UFMA, 1983);

d (Batista \& Rêgo, 1996);

e (Castro, 2001);

f (Pinheiro-Junior et al ., 2005);

g (Carvalho-Neta \& Castro, 2008);

h (Eliott et al. , 2007).

The cluster analysis based on presence/absence data (Fig. 2) separated the estuaries into two distinct groups (A and $\mathrm{B}-$ west and east of the Gurupi river, respectively), with a similarity level of only $30 \%$. The SIMPROF test confirmed that significant differences between these groups only exist in relation to geographical proximity. 


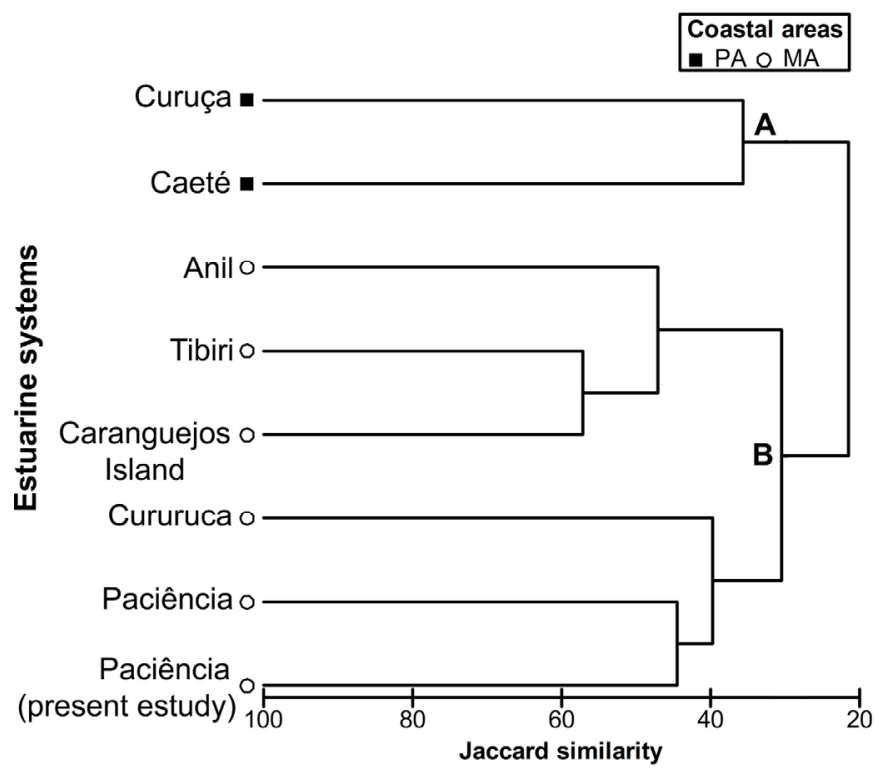

Figure 2. Dendrogram of cluster analysis of matrix presence/absence data, demonstrating similarity of estuarine systems of northern Brazil in terms of fish assemblage composition

\section{Discussion}

According to Barletta et al. $(2003,2005)$, the variation in the salinity gradient occurred due to salinity, demonstrating a seasonal trend in the estuarine environments. Previous studies indicate that fluctuations in salinity may be considered a primary factor influencing the distribution patterns of juvenile fish along an estuarine ecocline (Barletta et al., 2005, 2008). However, Blaber (2007) states that substrate type, depth and turbidity may be more important factors to determining the distribution of juvenile fish in tropical estuaries than salinity.

The data from the present study corroborate Blaber's statements, as the Curuçá and Caeté estuaries in the state of Pará are influenced by the Amazon River, where the high degree of turbidity and sedimentation make the environment propitious to the development of estuarine species. These features can therefore be considered determinants of the occurrence of juveniles in these estuarine systems. In the Cururuca estuary, the broad tidal ranges, together with the availability of detritus from the mainland, contribute toward waters rich in suspended matter, favoring the occurrence of a large number of juveniles in this estuary.

Krumme and Liang (2004) report that the number of species and species-to-family ratio are likely linked to habitat accessibility and food availability. This is observed in the estuaries of the state of Pará (influenced by discharge from the Amazon River) and in the Maranhense Gulf, which is a macro-tidal zone. Thus, it remains unclear whether there are latitudinal trends in the species-to-family ratio and its ecological potential or bio-geographical significance (Moraes et al., 2009).

The diversity values found on the coast of Pará and Maranhão were lower than those recorded in similar studies on fish assemblages carried out in northeastern Brazil. In the state of Paraiba, Nunes and Rose (1998) report a maximal diversity of 2.46. Santos (2000) reports diversity exceeding 3.0 on the coast of Pernambuco. Moraes et al. (2009) obtained an accumulated diversity of 2.79 on the coast of Ilhéus in the state of Bahia. The difference in diversity values may have been caused by changes in biotic and/or abiotic variables. However, the discrepancy in values in relation to those from previous studies may have been influenced by the characteristics of each ecosystem.

With regard to the reduction in the occurrence of species and the increase in diversity in the Paciência estuary, Barletta et al. (2005) report that seasonal changes in estuarine fish assemblages may be determined by a combination of temporal fluctuations in the abundance of species induced by rainfall as well as the reproduction and recruitment of marine, estuarine and freshwater species.

According to Barletta and Blaber (2007), the considerable tolerance of Ariidae species to areas with turbid waters and low salinity explains why this family is dominant in estuarine-resident fish assemblages throughout its worldwide distribution. Carvalho Neta et al. (2006) state that, in addition to these features, C. spixii, C. 
agassizii and S. herzbergii have generalist opportunist feeding habits, which enable juveniles and adults to remain longer in estuaries. These findings were corroborated in the present study, as Ariidae species did not exhibit a defined geographic distribution among the tidal creeks west and east of the Gurupi River. However, Giarrizzo and Krumme (2008) found a greater abundance of Ariidae in the estuarine system of the Caete estuary in comparison to the Curuçá estuary. The authors conclude that this occurrence may be associated with greater input in the Caeté system and, hence, a larger drift of sediment, than an increase in the number of individuals from this family in the tidal creeks of the Caeté estuary.

In the São Marcos and São José bays, adults of the most abundant engraulids use the coastal habitat and migrate to the inner waters of the estuary to spawn. However, these fish use the area under the greatest influence by the ocean for recruitment and development (Pessanha et al., 2000). Spatial separation may reflect adaptations to different environmental conditions or a strategy to avoid competition (Silva et al., 2003). In the Caeté estuary, the increase in Engraulidae biomass is likely related to an increased production of plankton toward the mouth of the Amazon River (DeMaster and Pope, 1996; Krumme and Saint-Paul, 2010).

The considerable abundance of Haemulidae and Mugilidae is likely due to a strong marine influence on São Luís Island (Giarrizzo and Krumme, 2008). Moreover, Vieira and Music (1994) report the numerical dominance of Haemulidae and Mugilidae, mainly associated with the tropical estuaries of the region. These studies indicate a trend similar to that found in the tidal creeks analyzed in the present investigation.

Cynoscion acoupa occurred in both the outer and inner portions of the Maranhense Gulf, because fish of the family Sciaenidae tolerate a wide range of salinity, which allows them to inhabit estuaries under the strong influence of freshwater (Camargo and Isaac, 2003; Matos and Lucena, 2006). With regard to Tetraodontidae, Giarrizzo and Krumme (2008) state that the strong marine influence and huge tidal range in São Marcos Bay can influence the proportion of low-mass species from this family on São Luís Island.

Regarding the classification of species according to functional group based on estuary use, Elliot et al. (2007) argue that the low contributions of marine "occasional visitor" species and freshwater species reflects the physiologically stressful nature of transitional waters of the freshwater-seawater interface. The absence of marine "occasional visitor" species in the inner portion of the Maranhense Gulf was likely due to the low salinity $(<16)$, which is reported to be a stressor for marine fish, restricting the type and number of species in a particular area (Bulger et al., 1995).

Garcia and Vieira (2001) and Barletta and Saint-Paul (2010) argue that the greater relative biomass of freshwater species in estuarine environments may be due mainly to the high degree of river discharge. The authors also assume that the fresh water level and flow toward the estuary increase in the late rainy season, leading to a decline in salinity, which enables creatures from freshwater environments to reach estuarine environments. However, the group of marine species had a low contribution in catches in the tidal creeks on the coast of Pará, indicating that this group of marine species only enters this region to perform certain biological functions, such as feeding and breeding (Carvalho-Neta and Castro, 2008). According to Barletta-Bergan (2010), these habitats are not preferred by the larvae of many marine species due to the high degree of turbidity and seasonal variations in salinity. The author states that the sciaenid C. acoupa is the only marine species with extensive use of mangrove intertidal creeks in the Caeté estuary as nurseries.

According to a survey carried out by Andrade-Tubino et al. (2008), the northern and northeastern regions of the Brazilian coast have the highest numbers of estuarine-resident species. This pattern of occurrence is due to environmental characteristics and the behavior of species, which is mainly related to trophic and reproductive migrations, with a uniformity of occurrence among the fish fauna in estuarine environments (Castro, 1997).

Regarding the feeding pattern of the species, detritivores occurred preferentially along of estuarine systems of the coast of the state of Pará. In a previous study carried out in the same estuary region, Krumme et al. (2004) also found that detritivores dominated the fish fauna of the mangrove tidal creeks of the Caete estuary. When the food supply is mainly based on the consumption of debris, most of the fish production is trapped in the near-shore estuarine system (Krumme and Saint-Paul, 2010). Studies addressing trophic guilds in the tidal creeks in the Maranhense Gulf indicate uniformity in the diet of the fish species caught, mainly because few tropical species have specialized feeding habits (Abelha, 2001). Most species are generalists, with some degree of preference in the use of available resources in the environment (Pereira et al., 2007).

Based on the feeding mode functional group, more than half the species occurring in the Maranhense Gulf were detritivores and zoobenthivores. In a comparative study, Giarrizzo and Krumme (2008) also found that the contribution of zoobenthivorous species in the creeks of Maranhão was approximately fivefold greater than in the creeks of Pará. In the present study, engraulids exhibited zooplanktivorous and herbivorous habits, especially 
in tidal creeks under greater marine influence. Addressing the feeding habits of two species of Engraulidae, Sergipense et al. (1999) stress the fact that these are typically planktivorous fish. However, different species have different food preferences (zooplankton or phytoplankton).

The contrast of the low occurrence of piscivores in relation to the high abundance of juveniles in the Para and Maranhão estuarine systems, demonstrates that intertidal mangrove creeks are important nursery areas for many fish populations along the northern coast of Brazil (Barletta-Bergan et al., 2002b; Giarrizzo and Krumme, 2008; Krumme and Saint-Paul, 2010). According to a number of authors, a high occurrence of juveniles may be associated with the high productivity of a given system (Clough, 1998; Dittmar and Lara, 2001), the low risk of predation due to the structural heterogeneity of mangrove habitats (Laegdsgaard and Johnson, 2001) and a high degree of water turbidity (Krumme et al., 2004). This underscores the importance of this ecosystem to the development of recruits (Dantas et al., 2010).

According to the information available in the relevant literature, the spatial and seasonal differences in the fish assemblages in each region may be linked to spatial heterogeneity and the characteristics of the adjacent marine areas as well as the considerable tolerance of species to variations in salinity. Moreover, landscape factors, such as the position of the creeks relative to the ocean or continent, likely also play a significant role in the differences in the composition of the fish fauna in intertidal creeks of mangroves, regardless of salinity (Giarrizzo and Krumme, 2007). This suggests that the combination of the geomorphology of the estuary and drainage of the river basin influences the distribution of fish assemblages in the ecocline of an estuarine ecosystem (Barletta et al., 2010).

Understanding the variations in the fish fauna on different spatial and temporal scales can provide valuable insights for management and conservation strategies (Barletta et al., 2010). Moreover, it is postulated that trophic relationships and breeding cycles also have critical importance in the spatial-temporal distribution of estuarine fish fauna (Andrade-Tubino et al., 2008).

In conclusion, the present investigation indicates that the coastal region between the states of Pará and Maranhão (Brazil) is characterized by high dynamics and environmental heterogeneity, particularly with regard to changes in river discharge and tidal fluctuations. In relation to the dominance of juveniles of almost all fish species, the estuarine systems analyzed provide important ecological conditions to the breeding of fish assemblages, which are targets for local fishing activities. Tetraodontidae were the most representative group on the coast of Pará and the abundance of species from this family was strongly influenced by the hydrodynamics of the Amazon River. Consequently, the increased discharge of fresh water in estuaries in the state of Pará favors the occurrence of this group.

The environmental characteristics of the northern coast of Brazil create favorable conditions for the occurrence of estuarine species, but do not limit the presence of marine and freshwater species, allowing these groups to contribute to local catches. Thus, the protection of estuarine systems should be considered an essential action for the management of fishery resources, since there is a strong relationship between abundance of fish fauna and composition of the habitat. However, although this coastal region is very rich and has one of the largest continuous areas of mangrove in the world, there is insufficient information on the northern coast of Brazil for an accurate determination of the general spatial relationship between the characteristics of the intertidal creeks of the mangrove and the fish assemblage structure. Therefore, additional studies on trophic ecology associated with other biological aspects of the species can provide important information for planning the rational management of fishery resources in the coastal region between the states of Pará and Maranhão, Brazil.

\section{Acknowledgments}

This study received financial support from the National Council for Scientific and Technological Development (CNPq) through a scholarship (Process $\mathrm{N}^{\mathrm{0}}$ 141642/2008-4) granted to the first author through the Postgraduate Program in Aquatic Ecology and Fisheries (PPEAP/UFPA).

\section{References}

Abelha, M. C. F., Agostinho, A. A., \& Gourlat, E. (2001). Plasticidade trófica em peixes de água doce. Acta Scie., $23,425-434$.

Andrade-Tubino, M. F., Ribeiro, A. L. R., \& Vianna, M. (2008). Organização espaço-temporal das ictiocenoses demersais nos ecossistemas estuarinos brasileiros: Uma síntese. Oecol. Bras., 12, 640-661. https://doi.org/10.4257/oeco.2008.1204.05

Barletta, M., \& Blaber, S. J. M. (2007). Comparision of fish assemblage and guilds in tropical habitats of the Embley (Indo-West Pacific) and Caeté (Western Atlantic) estuaries. Bull. Mar. Sci., 80, 647-680. 
Barletta, M., \& Saint-Paul, U. (2010). Distribution Pattern of Fish in a Mangrove Estuary. In Saint-Paul, U., \& Schneider, H. (Eds.), Mangrove Dynamics and Management in North Brazil (pp. 171-188). Ecological Studies, Berlin Heidelberg: 211. https://doi.org/10.1007/978-3-642-13457-9_11

Barletta, M., Amaral, C. S., Corrêa, M. F. M., Guebert, F., Dantas, D. V., Lorenzi, L., \& Saint-Paul, U. (2008). Factors affecting seasonal variations in demersal fish assemblages at an ecocline in a tropical-subtropical estuary. J. Fish Biol., 73, 1314-1336. https://doi.org/10.1111/j.1095-8649.2008.02005.x

Barletta, M., Barletta-Bergan, A., Saint-Paul, U., \& Hubold, G. (2003). Seasonal changes in density, biomass, and diversity of estuarine fishes in tidal mangrove creeks of the lower Caeté Estuary (northern Brazilian coast, east Amazon). Mar. Ecol. Progr. Ser., 256, 217-228. https://doi.org/10.3354/meps256217

Barletta, M., Barletta-Bergan, A., Saint-Paul, U., \& Hubold, G. (2005). The role of salinity in structuring the fish assemblages in a tropical estuary. J. Fish Biol., 66, 45-72. https://doi.org/10.1111/j.0022-1112.2005.00582.x

Barletta, M., Jaureguizar, A. J., Baigun, C., Fontoura, N. F., Agostinho, A. A., Almeida-Val, V. M. F., ... Corrêa, M. F. M. (2010). Fish and aquatic habitat conservation in South America: a continental overview with emphasis on neotropical systems. J. Fish Biol., 76, 2118-2176. https://doi.org/10.1111/j.1095-8649.2010.02684.x

Barletta-Bergan, A. (2010). An Evaluation of the Larval Fish Assemblage in a North Brazilian Mangrove Area. In Saint-Paul, U., \& Schneider, H. (Eds.), Mangrove Dynamics and Management in North Brazil (pp. 209-220). Ecological Studies, Berlin Heidelberg: 211. https://doi.org/10.1007/978-3-642-13457-9_13

Barletta-Bergan, A., Barletta, M., \& Saint-Paul, U. (2002a). Community structure and temporal variability of ichthyoplankton in North Brazilian mangrove creeks. J. Fish Biol., 61, 33-51. https://doi.org/10.1111/j.1095-8649.2002.tb01759.x

Barletta-Bergan, A., Barletta, M., \& Saint-Paul, U. (2002b). Structure and seasonal dynamics of larval fish in the Caeté River Estuary in North Brazil. Estuar. Coast. Shelf Sci., 54, 193-206. https://doi.org/10.1006/ecss.2001.0842

Batista, V. D. S., \& Rêgo, F. N. (1996). Análise de associações de peixes em igarapés do estuário do rio Tibiri, Maranhão. Rev. Bras. Biol., 56, 163-176.

Blaber, S. J. M. (2007). Mangroves and fishes: Issues of diversity, dependence, and dogma. Bull. Mar. Sci., 80, 457-472.

Bulger, A. J., Lowery, T. A., \& Monaco, M. E. (1995). Characterizing the estuarine-catadromus life history strategy. In Bulger, A. J., Lowery, T. A., \& Monaco, M. E. (Eds.), Estuarine-catadromy: a life history strategy coupling marine and estuarine environments via coastal inlets (pp. 1-44). Silver Springer: 14.

Camargo, M., \& Isaac, V. (2003). Ictiofauna estuarina. In Fernandes, M. E. B., \& Fundação Rio Bacanga (Eds.), Os manguezais da costa norte brasileira (p. 142).

Carvalho Neta, R. N. F., \& Castro, A. C. L. (2008). Diversidade das assembléias de peixes estuarinos da Ilha dos Caranguejos, Maranhão. Arqui. Ciên. Mar, 41, 48-57.

Carvalho Neta, R. N. F., Sousa-Neto, A. M. S., \& Silva, F. H. R. (2006). Dieta de Arius herzbergii na Ilha dos Caranguejos, Maranhão. In Resumos do XXVI Congresso Brasileiro de Zoologia. Londrina.

Castro, A. C. L. (1997). Características ecológicas da ictiofauna da Ilha de São Luís - MA. Bol. Lab. Hidro., 10, $1-18$.

Castro, A. C. L. (2001). Diversidade da assembléia de peixes em igarapés do estuário do rio Paciência (MA Brasil). Atlân., 23, 39-46.

Clarke, K. R., \& Warwick, R. M. (2001). Change in marine communities: An approach to statistical analysis and interpretation. Natural Environment Research Council, Plymouth.

Clough, B. (1998). Mangrove forest productivity and biomass accumulation in Hinchinbrook Channel, Australia. Mangr. Salt Marsh., 3, 9-15.

Dantas, D. V., Barletta, M., Costa, M. F., Barbosa-Cintra, S. C. T., Possatto, F. E., Ramos, J. A. A., ... Saint-Paul, U. (2010). Movement patterns of catfishes (Ariidae) in a tropical semi-arid estuary. J. Fish Biol., 76, 2540-2557. https://doi.org/10.1111/j.1095-8649.2010.02646.x

Demaster, D. J., \& Pope, R. H. (1996). Nutrient dynamics in Amazon shelf waters: results from AMASSEDS. Conti. Shelf Res., 16, 263-289. https://doi.org/10.1016/0278-4343(95)00008-O 
Dittmar, T., \& Lara, R. J. (2001). Driving forces behind nutrient and organic matter dynamics in a mangrove tidal creek in North Brazil. Estuar. Coast. Shelf Sci., 52, 249-259. https://doi.org/10.1006/ecss.2000.0743

Elliott, M., Whitfield, A. K., Potter, I. C., Blaber, S. J. M., Cyrus, D. P., Nordlie, F. G., \& Harrison, T. D. (2007). The guild approach to categorizing estuarine fish assemblages: a global review. Fish and Fishe., 8, 241-268. https://doi.org/10.1111/j.1467-2679.2007.00253.x

Froese, R., \& Pauly, D. (Eds.). (2010). FishBase. Retrieved July 21, 2006, from http://www.fishbase.org

Garcia, A. M., \& Vieira, J. P. (2001). O aumento da diversidade de peixes no estuário da lagoa dos patos durante o episódio El niño 1997-1998. Atlân., 23, 133-152.

Giarrizzo, T., \& Krumme, U. (2007). Spatial differences and seasonal cyclicity in the intertidal fish fauna from four mangrove creeks in a salinity zone of the Curuçá estuary, North Brazil. Bull. Mar. Sci., 80, 739-754.

Giarrizzo, T., \& Krumme, U. (2008). Heterogeneity in intertidal fish fauna assemblages along the world's longest mangrove area in northern Brazil. J. Fish Biol., 72, 773-779. https://doi.org/10.1111/j.1095-8649.2007.01728.x

Giarrizzo, T., \& Krumme, U. (2009). Temporal patterns in the occurrence of selected tropical fishes in mangrove creeks: implications for the fisheries management in north Brazil. Braz. Arch. Biol. Technol., 52, 679-688. https://doi.org/10.1590/S1516-89132009000300020

Gibson, R. N. (1982). Recent studies on the biology of intertidal fishes. Ocea. Mar. Biol. Ann. Rev., 20, 363-414.

Kjerfve, B., \& Lacerda, L. D. (1993). Mangroves of Brazil. In Lacerda, L. D. (Ed.), Mangrove ecosystems technical reports ITTO TS-13 (pp. 245-272).

Krumme, U., \& Liang, T. H. (2004). Tidal induced changes in a copepod dominated zooplankton community in a macrotidal mangrove channel in northern Brazil. Zoo. Stud., 43, 404-414.

Krumme, U., \& Saint-Paul, U. (2010). Dynamics in Mangrove Fish Assemblages on a Macrotidal Coast. In Saint-Paul, U., \& Schneider, H. (Eds.), Mangrove Dynamics and Management in North Brazil (pp. 189-207). Ecological Studies, Berlin Heidelberg: 211. https://doi.org/10.1007/978-3-642-13457-9_12

Krumme, U., Saint-Paul, U., \& Rosenthal, H. (2004). Tidal and diel changes in the structure of a nekton assemblage in small intertidal mangrove creeks in northern Brazil. Aqua. Liv. Resou., 17, 215-229. https://doi.org/10.1051/alr:2004019

Laegdsgaard, P., \& Johnson, C. R. (2001). Why do juvenile fish utilize mangrove habitats? J. Exp. Mar. Biol. Eco., 257, 229-253. https://doi.org/10.1016/S0022-0981(00)00331-2

Layman, C. A., \& Silliman, B. R. (2002). Preliminary survey and diet analysis of juvenile fishes of an estuarine creek on Andros Island, Bahamas. Bull. Mar. Sci., 70, 199-210.

Matos, I. P., \& Lucena, F. (2006). Descrição da pesca da pescada-amarela, Cynoscion acoupa, da costa do Pará. Arqui. Ciên. Mar, 39, 66-73.

MMA. (2002). Avaliação e identificação de áreas e ações prioritárias para a conservação, utilização sustentável e repartição dos beneficios da biodiversidade nos biomas brasileiros. MMA/SBF, Brasília.

Moraes, L. E., Romero, R. D. M., Rocha, G. R. A., \& Moura, R. L. D. (2009). Demersal ichthyofauna of the inner continental shelf of Ilhéus, Bahia, Brazil. Bio. Neotr., 9, 163-168. https://doi.org/10.1590/S1676-06032009000400016

Nunes, C. R. R., \& Rosa, R. S. (1998). Composição e distribuição da ictiofauna acompanhante em arrastos de camarão na costa da Paraíba, Brasil. Trab. Ocean. Uni. Fed. Per., 26, 67-83.

Pereira, P. R., Agostinho, C. S., Oliveira, R. J., \& Marques, E. E. (2007). Trophic guilds of fishes in sandbank habitats of a Neotropical river. Neo. Ichthyol., 5, 399-404. https://doi.org/10.1590/S1679-62252007000300019

Pessanha, A. L. M., Araújo, F. G., Azevedo, M. C. C., \& Gomes, I. D. (2000). Variações temporais e espaciais na composição e estrutura da comunidade de peixes jovens da baía de Sepetiba, Rio de Janeiro. Rev. Bras. Zoo., 17, 251-261. https://doi.org/10.1590/S0101-81752000000100022

Pinheiro-Júnior, J. R., Castro, A. C. L., \& Gomes, L. N. (2005). Estrutura da comunidade de peixes do estuário do rio Anil, Ilha de São Luís, Maranhão. Arqui. Ciên. Mar, 38, 29-37.

Rountree, R. A., \& Able, K. W. (1997). Nocturnal fish use of New Jersey marsh creek and adjacent bay shoal 
habitats. Estuar. Coast. Shelf Sci., 44, 703-711. https://doi.org/10.1006/ecss.1996.0134

Rozas, L. P., \& Zimmerman, R. J. (2000). Small-scale patterns of nekton use among marsh and adjacent shallow nonvegetated areas of the Galveston Bay Estuary, Texas (USA). Mar. Ecol. Progr. Ser., 193, 217-239. https://doi.org/10.3354/meps193217

Santos, M. C. F. (2000). Diversidade biológica da ictiofauna acompanhante nas pescarias de camarões em Tamandaré (Pernambuco - Brasil). Bol. Téc. Cient. CEPENE, 8, 165-183.

Sergipense, S., Caramaschi, E. P., \& Sazima, I. (1999). Morfologia e hábitos alimentares de duas espécies de Engraulidae (Teleostei, Clupeiformes) na baía de Sepetiba, RJ. Rev. Bras. Ocean., 47, 173-188. https://doi.org/10.1590/S1413-77391999000200006

Silva, M. A., Araújo, F. G., Azevedo, M. C. C., \& Mendonça, P. (2003). Distribuição espacial e temporal de Cetengraulis edentulus (Cuvier) (Actinopterygii, Engraulidae) na Baía de Sepetiba, Rio de Janeiro, Brasil. Rev. Bras. Zoo., 20, 577-581. https://doi.org/10.1590/S0101-81752003000400003

Souza Filho, P. W. M. (2005). Costa de manguezais de macromaré da Amazônia: cenários morfológicos, mapeamento e quantificação a partir de dados de sensores remotos. Rev. Bras. Geof., 23, 427-435. https://doi.org/10.1590/S0102-261X2005000400006

Spach, H. L., Santos, C., Godefroid, R. S., Nardi, M., \& Cunha, F. (2004). A study of the fish community structure in a tidal creek. Braz. J. Biol., 64, 337-351. https://doi.org/10.1590/S1519-69842004000200020

Stride, R. K. (1992). Diagnóstico da pesca artesanal marinha do estado do Maranhão. CORSUP/EDUFMA, São Luís.

SUDAM/UFMA. (1983). Caracterização ambiental e prospecção pesqueira do estuário do rio Cururuca Maranhão. (SUDAM, ed.), p. 141. Belém, Publicações SUDAM.

Viana, A. P., Lucena Frédou, F., Frédou, T., Torres, M. F., \& Bordalo, A. O. (2010). Fish fauna as an indicator of environmental quality in an urbanised region of the Amazon estuary. J. Fish Biol., 76, 467-486. https://doi.org/10.1111/j.1095-8649.2009.02487.x

Vidy, G. (2000). Estuarine and mangrove systems and the nursery concept: which is which? The case of the Sine Saloum system (Senegal). Wetl. Ecol. Man., 8, 37-51. https://doi.org/10.1023/A:1008402905530

Vieira, J. P., \& Music, J. A. (1994). Fish faunal composition in warm-temperate and tropical estuaries of western Atlantic. Atlân., 16, 31-53.

\section{Appendix}

\section{Supplementary material}

Supplementary material associated with this article, containing a list of species according to estuary use and functional feeding mode in estuarine systems.

\section{Copyrights}

Copyright for this article is retained by the author(s), with first publication rights granted to the journal.

This is an open-access article distributed under the terms and conditions of the Creative Commons Attribution license (http://creativecommons.org/licenses/by/4.0/). 